\begin{tabular}{|c|c|}
\hline 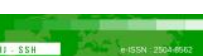 & Malaysian Journal of Social Sciences and Humanities (MJSSH) \\
\hline Malaysian Journal of & Volume 5, Issue 12, December 2020 \\
\hline (MJ-SSH) & e-ISSN : 2504-8562 \\
\hline & $\begin{array}{l}\text { Journal home page: } \\
\text { www.msocialsciences.com }\end{array}$ \\
\hline
\end{tabular}

\title{
Toleransi Penduduk Bumiputera Terhadap Kaum Cina di Sabah: Kajian Kes dalam kalangan Pelajar Sekolah Menengah di Kota Kinabalu, Sabah
}

\author{
Budi Anto Mohd Tamring1, Saidatul Nornis Hj. Mahali1 \\ 1Pusat Penataran Ilmu dan Bahasa, Universiti Malaysia Sabah (UMS) \\ Correspondence: Budi Anto Mohd Tamring(budi@ums.edu.my)
}

\begin{abstract}
Abstrak
Isu hubungan antara masyarakat tempatan dengan masyarakat keturunan imigran merupakan isu biasa dalam mana-mana negara di seluruh dunia. Kesan penjajahan pada suatu masa dahulu telah menyebabkan komposisi penduduk di sesebuah negara pada hari ini telah bercampur malah sesetengah negara telah mengalami pertambahan penduduk yang agak drastik kesan daripada pengaruh penjajahan yang membawa penduduk dari tempat lain ke kawasan jajahan mereka. Pergerakan masyarakat kesan daripada keperluan ekonomi mahupun untuk keselamatan akhirnya juga menyebabkan sesebuah negara menerima ramai imigran. Malaysia sendiri telah melalui pengalaman demikian dan komposisi penduduk khususnya di Tanah Melayu memperlihatkan kemasukan orang Cina dan India secara besar-besaran semasa penjajahan British. Hubungan masyarakat Melayu dengan kaum imigran ini sehingga kini sering kali menimbulkan pelbagai masalah dan digambarkan sebagai mempunyai hubungan pasang surut. Malah kemuncak kepada hubungan tersebut adalah dengan tercetusnya peristiwa 13 Mei 1969. Justeru itu, kajian ini yang menggunakan soal-selidik dan melibatkan seramai 731 orang pelajar di sekolah menengah bertujuan untuk melihat bagaimana toleransi penduduk Bumiputera Sabah khususnya pelajarpelajar di sekolah Menengah terhadap kaum Cina. Penduduk Sabah dan khususnya Kota Kinabalu juga memiliki ramai penduduk Cina dan komposisi ini amat sesuai untuk menguji penerimaan masyarakat Bumiputera terhadap kaum Cina. Hasil kajian mendapati toleransi pelajar Bumiputera adalah tinggi terhadap kaum Cina. Dapatan kajian ini agak selari dengan kajian-kajian lepas yang mengatakan penduduk Sabah mempunyai tahap toleransi etnik yang tinggi.
\end{abstract}

Kata kunci: toleransi etnik, hubungan kaum, bumiputera, Cina

\section{Bumiputera Tolerance Towards the Chinese in Sabah: A Case Study Among Secondary School Students in Kota Kinabalu, Sabah}

\begin{abstract}
The issue between local and immigrant descendent communities is common in any country around the world. The effects of past colonialism affect the present mixed population composition of a country; some countries experienced a relatively drastic increase in population due to the influence of colonialism that brought people from other places to their colonies. The movement of society as a result of economic needs as well security has ultimately caused a country to accept many immigrants. Malaysia itself went through this experience and the composition of the population, especially in Malaya showed huge migration of the Chinese and Indian during the British occupation. The relationship between the Malays and the immigrant often caused problems till now and the relationship has its ups and downs. In fact, it
\end{abstract}


was this relationship that triggered May 13, 1969 incident. This study uses questionnaire and which involves a total of 731 students in secondary schools which aims to see how tolerant the Bumiputera population of Sabah, especially students in secondary schools are, towards the Chinese. The people of Sabah and especially in Kota Kinabalu has a large Chinese population and this composition is very suitable to test the acceptance of the Bumiputera community towards the Chinese. The results of the study found that the tolerance level of Bumiputera students is high towards the Chinese. The findings of this study are quite in line with previous studies that say the people of Sabah have a high level of ethnic tolerance.

Keywords: ethnic tolerance, ethnic relation, bumiputera, Chinese

\section{Pengenalan}

Sabah merupakan negeri yang kaya dengan keanekaragaman penduduknya. Percampuran kaum di Sabah agak tinggi melibatkan penduduk tempatan, penduduk keturunan imigran dan juga pendatang asing. Selain daripada faktor penjajahan, perkembangan ekonomi yang pesat khususnya dalam industri perladangan dan pembinaan menyebabkan kemasukan pekerja asing ke Sabah juga tinggi. Malah kedudukan negeri Sabah yang dikelilingi dengan sempadan negara Filipina dan Indonesia juga menyebabkan negeri ini menjadi tumpuan penduduk dari kedua-dua negara tersebut untuk mencari rezeki. Demikian juga kemasukan orang Cina di Sabah telah dikesan berlaku disebabkan oleh pengaruh penjajahan. Pertapakan British North Borneo Chartered Company (BNBCC) di Borneo Utara yang ditubuhkan pada tahun 1881 telah mendorong penghijrahan orang-orang Cina Hakka ke Sabah secara besar-besaran (Bih Ni, Lee. 2012). Bilangan Penduduk Cina di Sabah sehingga kini juga agak tinggi malah kebanyakan bandar-bandar utama di Sabah juga dikuasai oleh orang Cina. Data Jabatan Perangkaan Tahun 2010 seperti yang ditunjukkan dalam Jadual 1 menyatakan sebanyak 9.2\% daripada 3206742 orang penduduk di Sabah adalah kaum Cina.

Jadual 1 : Komposisi Penduduk Negeri Sabah Tahun 2010

\begin{tabular}{lcc}
\hline Etnik/Kaum & Jumlah & Peratus (\%) \\
\hline Melayu & 184197 & 5.74 \\
Kadazandusun & 568575 & 17.73 \\
Bajau & 450279 & 14.04 \\
Murut & 102393 & 3.19 \\
Bumiputera Lain & 659865 & 20.58 \\
Cina & 295674 & 9.22 \\
India & 7453 & 0.23 \\
Lain-lain & 48527 & 1.51 \\
Penduduk Bukan Warganegara & 889779 & 27.75 \\
Jumlah Keseluruhan & $\mathbf{3 2 0 6 7 4 2}$ & $\mathbf{1 0 0}$ \\
\hline Surut:
\end{tabular}

Sumber: https://www.statistics.gov.my/censusatlas/images/ReligionEN.pdf

Jika dilihat secara khusus di Kota Kinabalu pula, komposisi penduduk seperti yang ditunjukkan dalam jadual 2 memperlihatkan bilangan penduduk Cina yang ramai. Perbandingan berdasarkan kategori etnik menunjukkan penduduk Cina merupakan penduduk yang paling ramai di Kota Kinabalu berbanding kategori etnik lain yang berstatus warganegara. Percampuran penduduk Cina dengan penduduk tempatan boleh dikatakan agak tinggi di Kota Kinabalu bersesuaian persekitaran yang mereka kongsikan bersama membentuk pelbagai interaksi sama ada dalam konteks perhubungan sosial, politik mahupun ekonomi. Kehadiran penduduk Cina yang ramai di Kota Kinabalu sudah tentunya dipegaruhi oleh fungsi bandar Kota Kinabalu sebagai ibu negeri Sabah dan pusat kegiatan ekonomi negeri Sabah. Kegiatan ekonomi 
penduduk Cina yang majoritinya dalam sektor perniagaan telah menjadikan pusat bandar dan kawasan bandar sebagai tumpuan petempatan mereka.

Jadual 2 : Komposisi Etnik Di Kota Kinabalu 2014

\begin{tabular}{lcc}
\hline Kategori Etnik & Jumlah & Peratus \\
\hline Melayu & 36918 & 7.97 \\
Kadazandusun & 71335 & 15.41 \\
Bajau & 74731 & 16.14 \\
Murut & 2554 & 0.55 \\
Bumiputera lain & 60512 & 13.07 \\
Cina & 96852 & 20.92 \\
India & 2291 & 0.49 \\
Lain-lain & 5625 & 1.21 \\
lkan Warganegara & 112145 & 24.22 \\
& & $\mathbf{1 0 0}$ \\
\hline
\end{tabular}

Sumber: Buku Tahunan Jabatan Perangkaan Sabah. Statitic Yearbook 2014: 8-10

Percampuran penduduk Cina dan penduduk tempatan di Kota Kinabalu sehingga kini tidak pernah menimbulkan masalah. Berbeza dengan pengalaman masyarakat di Semenanjung Malaysia yang pernah berhadapan dengan konflik perkauman 13 Mei 1969 yang dipengaruhi oleh pelbagai faktor seperti isu bahasa, pendidikan dan ketidakseimbangan ekonomi mengikut kaum yang menyebabkan kemusanahan harta benda dan kehilangan nyawa (Mohd Sohaimi, Dayu, Budi Anto, 2011: 57). Di Kota Kinabalu dan umumnya di Sabah, tidak pernah direkodkan konflik perkauman terbuka antara penduduk tempatan dan penduduk Cina. Malah beberapa kajian lepas menunjukkan penduduk tempatan di Sabah berkahwin campur dengan penduduk Cina dan menghasilkan identiti kaum yang dikenali sebagai Sino. Perkahwinan campur yang menghasilkan idendtiti Sino dalam masyarakat juga diiktiraf sebagai Bumiputera Sabah (Herman, 2010). Perkahwinan campur yang tinggi dan penerimaan masyarakat mengiktiraf keturunan Sino sebagai penduduk Bumiputera Sabah menunjukkan penduduk Sabah mempunyai tahap toleransi etnik yang tinggi

Justeru itu, artikel ini bertujuan untuk menerangkan tahap toleransi kaum Bumiputera terhadap kaum Cina di Kota Kinabalu dengan menjadikan pelajar sekolah menengah sebagai responden kajian. Pelajar sekolah menengah dijadikan responden kajian kerana pelajar di peringkat ini sudah berfikiran matang. Pada peringkat ini mereka juga mula memahami dan mula mempunyai perasaan untuk menjalinkan hubungan dengan individu lain selain dari keluarga mereka. Malah dengan menjadikan pelajar sekolah menengah sebagai responden kajian maka secara langsung juga kita dapat memahami bagaimana kecenderungan perhubungan kaum antara pelajar di peringkat sekolah menengah. Dengan itu, hasil kajian ini sekurangkurangkan dapat memberikan input berkaitan situasi hubungan kaum di peringkat sekolah menengah. Hasil kajian juga secara tidak langsung boleh membantu pihak-pihak berkepentingan untuk merangka pelbagai program yang baik seawal di peringat sekolah menengah untuk memastikan hubungan yang baik antara pelajar pelbagai etnik terus harmoni.

\section{Sorotan Literatur}

Hubungan masyarakat pelbagai kaum dan agama di Sabah adalah baik dan seringkali dikatakan sebagai contoh yang perlu diikuti oleh masyarakat lain khususnya dalam integrasi dan perpaduan (Siti Aisyah, 2017). Beberapa kajian lepas yang dibuat di Sabah juga menunjukkan dapatan yang selari dengan kenyataan yang dibuat oleh ramai individu tentang keharmonian hubungan penduduk di Sabah (Budi Anto \& Saidatul, 2020). Keadaan masyarakat di Sabah yang harmoni dikatakan dipengaruhi oleh pelbagai faktor bermula dari identiti kaum dan agama yang bertindan lapis sehinggalah kepada pernanan institusi Tamu (Budi Anto, Bernadette \& Mohd Sohaimi, 2020) 
Kajian Sabihah (2007) yang bertajuk Toleransi Etnik dan Perpaduan Sosial di Negeri Sabah menjelaskan bahawa toleransi penduduk di Sabah adalah baik. Kntayya (2007) dalam kajian yang sama menjelaskan walaupun ada kecenderungan memilih kaum masing-masing khususnya dari segi politik tetapi kecenderungan tersebut harus dilihat sebagai sesuatu yang baik kerana menggalakkan masyarakat pelbagai etnik terlibat dalam politik dan seterusnya membentuk percampuran kuasa. Keadaan tersebut juga merupakan salah satu petunjuk toleransi yang tinggi. Begitu juga kajian Budi Anto (2008) yang bertajuk Pengaruh Agama dalam Interaksi dan toleransi Etnik: Kajian Kes Terhadap Pelajar Bumiputera Sabah di Universiti Malaysia Sabah juga mendapati tahap toleransi pelajar universiti adalah tinggi. Pelajar universiti yang dijadikan responden kajian adalah penduduk Bumiputera Sabah iaitu pelajar Bajau dan pelajar Kadazandusun.

Hubungan kaum di Sabah juga dikatakan baik jika dilihat dalam konteks kahwin campur. Kahwin campur di Sabah adalah tinggi dan perkahwinan campur yang berlaku bukan sahaja merentasi kaum tetapi juga melibatkan perkahwinan antara negara atau kewarganegaraan yang berbeza (Budi Anto \& Saidatul, 2020). Malah hubungan penduduk pelbagai kaum di Sabah juga dikatakan melangakui batas agama. Masyarakat tidak mengahadapi masalah untuk menjalinkan hubungan dengan masyarakat pelbagai kaum dan agama. Malah kajian lepas menunjukkan masyarakat pelbagai agama mempunyai penerimaan yang tinggi untuk menangani perbezaan dan konflik secara harmonis (Suraya et al., 2019).

Toleransi Etnik penduduk di Sabah juga bukan sahaja dapat dilihat melalui kahwin campur tetapi juga dapat dilihat bagaimana penduduk Sabah berupaya menerima individu lain yang berlainan kaum dan agama sebagai ahli keluarga mereka tanpa melibatkan perkahwinan tetapi hanya melalui ritual budaya yang dikenali sebagai mikorot. Mikorot merupakan ritual budaya yang memerlukan seseorang individu dengan beberapa individu lain melakukan ritual minum darah bersama untuk menjadikan mereka sebagai keluarga seperti hubungan adik beradik (Budi Anto, 2018). Selain itu, beberapa kajian lain seperti Kajian Kntayaa (2007), Hasan (2007), Budi Anto et al. (2020) juga memperlihatkan dapatan yang sama mengenai hubungan kaum di Sabah yang didapati adalah baik.

Beberapa kajian yang dinyatakan di atas didapati tiada yang memfokuskan kajian hubungan masyarakat Bumiputera terhadap kaum Cina di Sabah. Terdapat satu kajian terbaru bertajuk Ethnic Interaction Experience Of Chinese Ethnic Students: A Case Study In Universiti Malaysia Sabah (2020) tetapi kajian tersebut hanya merujuk interaksi pelajar Cina dan bukannya penerimaan masyarakat Bumiputera terhadap kaum Cina. Berlainan dengan kajian-kajian di Semenanjung Malaysia yang banyak mengkaji hubungan orang Melayu dengan Orang Cina. Kajian seperti Noor Aida (2009), Mansor Mohd. (2010), Mohamed Ali (2016) dan Harmiza (2015). Justeru itu, disebabkan keterbatasan kajian-kajian mengenai hubungan penduduk Bumiputera Sabah dengan kaum Cina maka artikel ini akan menjelaskan toleransi pelajar Bumiputera Sabah terhadap kaum Cina. Toleransi merupakan salah satu cara untuk mengukur hubungan dalam masyarakat sama ada baik ataupun sebaliknya. Kajian yang popular untuk mengukur hubungan antara kelompok dalam masyarakat adalah kajian Bogardus (1925) yang memperkenalkan skala jarak sosial dalam memahami hubungan antara masyarakat.

\section{Metod Kajian}

Kajian ini menggunakan kaedah kuantitatif dengan menggunakan soal-selidik sebagai alat pengumpulan data. Seramai 731 orang responden telah terpilih dalam kajian ini. Soal-selidik telah diedarkan kepada responden oleh penyelidik dan juga dengan bantuan pembantu penyelidik yang dilantik. Kawasan kajian adalah di kawasan Kota Kinabalu yang melibatkan pelajar yang dipilih daripada sembilan buah sekolah menengah mengikut kawasan di Kota Kinabalu yang dipecahkan kepada Menggatal, Telipok, Likas, Inanam, Luyang, Kepayan, Tanjung Aru dan Pusat Bandar. Pemilihan 9 buah sekolah daripada 19 buah sekolah harian biasa di Kota Kinabalu dibuat secara rawak menggunakan aplikasi https://www.randomizer.org. Memandangkan kajian ini bertujuan untuk melihat tahap toleransi pelajar Bumiputera terhadap kaum Cina maka secara langsung hanya pelajar Bumiputera sahaja yang terpilih sebagai responden kajian. Walau bagaimanapun hanya pelajar tingkatan 4 dan tingkatan 6 sahaja yang 
dijadikan sebagai responden kajian kerana umur bagi pelajar tingkatan 1 hingga 3 masih terlalu muda. Manakala pelajar tingkatan 5 tidak dipilih kerana Kementerian Pendidikan Malaysia tidak membenarkan pelajar yang terlibat dengan peperiksaan dijadikan sebagai responden kajian. Toleransi etnik dalam kajian ini diukur menggunakan nilai indeks seperti mana kaedah pengukuran toleransi etnik dalam kajian Kntayya Mariappan 2007 dan kajian Budi Anto Mohd Tamring 2008.

\section{Toleransi Etnik}

Toleransi etnik dalam kajian ini diterangkan menggunakan teori jarak sosial. Teori jarak sosial diperkenalkan oleh Park 1924 untuk memahami hubungan dalam masyarakat tetapi telah dipopularkan oleh Borgadus apabila Borgadus memperkenalkan skala pengukuran jarak sosial pada tahun 1925. Jarak sosial adalah konsep yang diperkenalkan sebagai usaha untuk mengurangkan jarak antara masyarakat. Jarak sosial menjelaskan sesuatu yang boleh diukur seperti tahap, label dan gred untuk memahami keintiman yang membentuk hubungan sosial secara umum atau di peringkat individu. Bogardus menjelaskan konsep jarak sosial sebagai tahap atau kedudukan untuk memahami keintiman yang terbentuk dalam hubungan sosial (Bogardus, 1925).

Jarak sosial umumnya merupakan satu cara untuk memahami hubungan antara masyarakat. Sekiranya jarak sosial adalah tinggi bermakna toleransi adalah rendah atau sekiranya jarak sosial adalah tinggi, maka prejudis dalam masyarakat juga adalah tinggi. Borgadus memperkenalkan tujuh item pengukuran jarak sosial iaitu (1) Menerima sebagai keluarga (berkahwin); (2) Menerima sebagai rakan rapat; (3) Menerima sebagai jiran; (4) Menerima sebagai rakan sekerja; (5) Menerima sebagai penduduk di negara ini; (6) Menerima sebagai pelawat dari negara luar; (7) Langsung tidak menerima kehadiran mereka ke negara ini (Bogardus, 1925). Justeru itu, toleransi etnik dalam artikel ini diukur berdasarkan penerimaan responden terhadap beberapa item hubungan yang diajukan kepada mereka seperti mana kaedah yang digunakan oleh Bogardus.

Walau bagaimanapun dalam kajian ini, item tersebut telah dikembangkan kepada 21 item yang merangkumi berkahwin, menjadi anak angkat, mengambil anak angkat, berkawan, tinggal sebilik, tinggal serumah, berjiran, rakan sekelas, duduk bersebelahan meja, menjamu selera, mejemput ke jamuan keluarga, hadir jamuan keluarga kaum Cina, keluar bersiar-siar, membantu, berkongsi perniagaan, berkongsi ruang perniagaan, rakan sekerja, berurus niaga, sepasukan dalam parti politik, sepasukan dalam pertubuhan sosial dan dipimpin. Kesemua 21 item ini juga dikembangkan dari item-item kajian Kntayya Mariappan (2007) dan Budi Anto Mohd Tamring (2008). Untuk mengukur tahap toleransi, kesemua item ini akan diberikan nilai berdasarkan respon responden melalui pilihan jawapan sangat setuju, setuju, sederhana setuju, tidak setuju dan sangat tidak setuju. Nilai skor secara keseluruhan dibahagikan jumlah item untuk mendapatkan nilai mean. Nilai mean tersebut digunakan sebagai petunjuk indeks tahap toleransi. Indeks toleransi responden ini akan ditentukan sama ada tinggi, sederhana atau rendah berdasarkan julat indeks yang ditunjukkan di bawah. Julat indeks ini sama seperti yang digunakan oleh ramai pengkaji lain yang menggunakan likert sale dalam kajian kuantitatif mereka (lihat kajian Landell, 1977; Nunally \& Bernstein,1994; Kamarul Azmi et al., 2011).
A. $\quad 3.68$ hingga 5.0
B. 2.34 hingga 3.67
C. $\quad 1.0$ hingga 2.33

$\begin{array}{ll}= & \text { Tinggi } \\ = & \text { Sederhana } \\ = & \text { Rendah }\end{array}$

\section{Hasil Kajian}

Tahap toleransi etnik responden terhadap kaum Cina akan diterangkan berdasarkan beberapa aspek yang merangkumi tahap toleransi secara umum, tahap toleransi mengikut agama, tahap toleransi mengikut aliran sekolah, tahap toleransi mengikut kawasan petempatan dan mengikut beberapa ciri-ciri latar belakang responden yang lain. 
Tahap toleransi pelajar Bumiputera terhadap kaum Cina seperti yang ditunjukkan dalam Jadual 3 adalah pada nilai indeks 4.04. Nilai ini menunjukkan tahap toleransi pelajar Bumiputera terhadap kaum Cina adalah tinggi. Secara keseluruhannya, kesemua item jenis hubungan yang diajukan kepada responden mempunyai nilai indeks toleransi yang tinggi kecuali empat jenis hubungan iaitu berkahwin, mengambil anak angkat, menjadi anak angkat dan dipimpin oleh orang Cina menunjukkan penerimaan yang sederhana. Ini bermakna walaupun pelajar Bumiputera menunjukkan tahap toleransi yang tinggi secara keseluruhannya terhadap kaum Cina tetapi dalam beberapa keadaan tertentu mereka juga agak kurang selesa khusunya yang melibatkan hubungan kekeluargaan dan juga dipimpin seperti yang telah dijelaskan di atas.

Dapatan kajian ini, menunjukkan persamaan dengan kajian Kntayaa (2007) yang menjelaskan tahap toleransi di Sabah adalah baik tetapi dalam masa yang sama menunjukkan sedikit sensitif apabila berkaitan dipimpin oleh kaum lain. Ini bermakna penduduk Sabah walaupun mempunyai tahap toleransi yang tinggi tetapi dalam masa yang sama mereka tetap mahu mempunyai pemimpin dari kaum masingmasing.

Jadual 3 : Tahap Toleransi Secara Umum

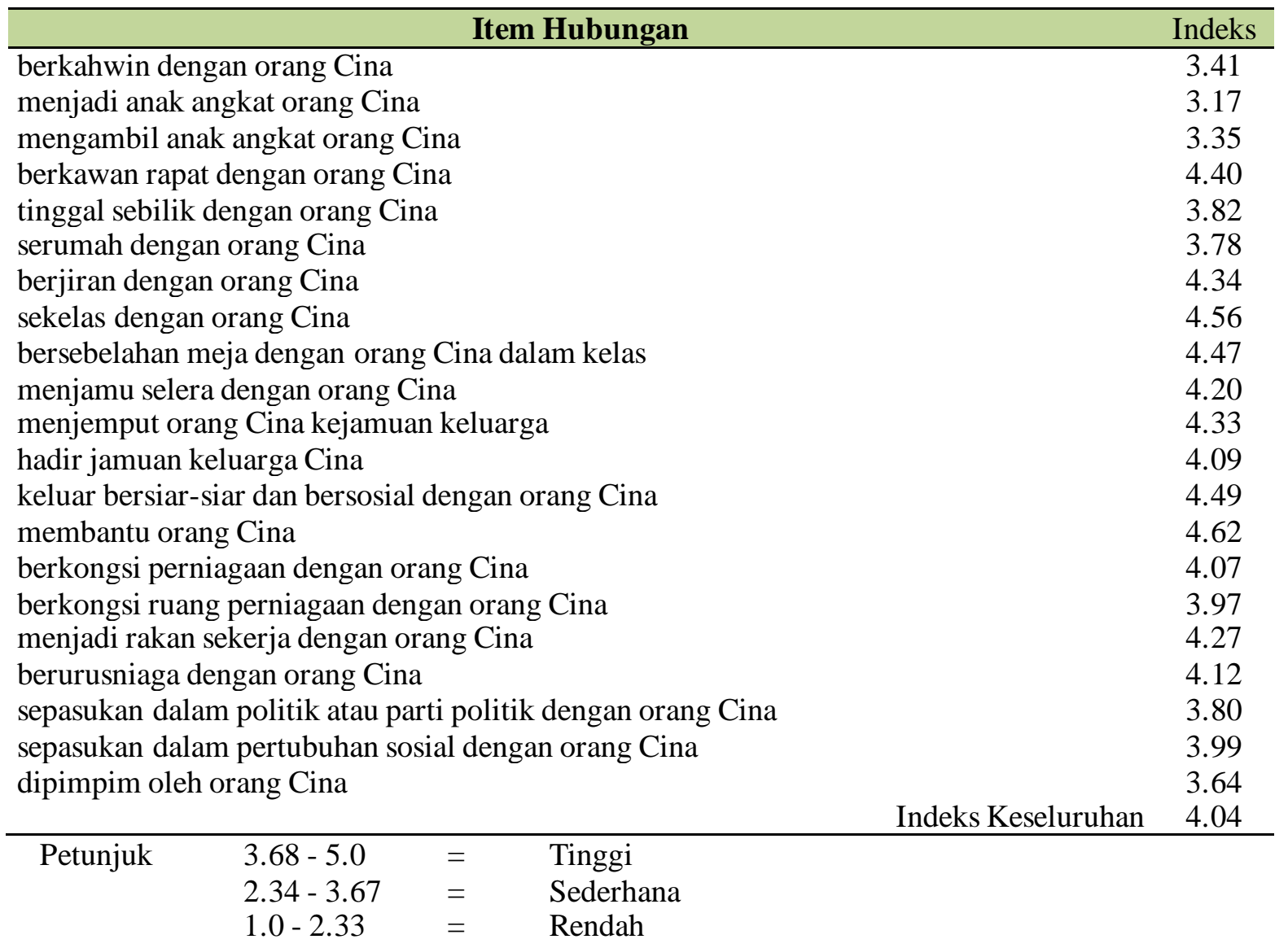

Jika dilihat secara khusus dalam konteks hubungan kekeluargaan pula, penerimaan responden yang sederhana terhadap berkahwin, menjadi anak angkat dan mengambil anak angkat adalah dipengaruhi oleh faktor agama. Bumiputera di Sabah terbahagi kepada dua kategori iaitu Bumiputera Islam dan Bumiputera bukan Islam. Bumiputera bukan Islam ini majoritinya adalah beragama Kristian dan sebilangan kecil beragama lain. Perkahwinan berlainan agama adalah amat ditegah dalam agama Islam dan tidak dibenarkan dalam undang-undang Malaysia. Penerimaan yang sederhana terhadap hubungan berkahwin, menjadi anak angkat dan mengambil anak angkat boleh jadi adalah dipengaruhi oleh sentimen responden Bumiputera Islam terhadap kaum Cina yang berlainan agama dengan mereka. Walaupun ada juga penduduk Cina yang beragama Islam tetapi bilangan tersebut terlalu kecil dan kebanyakannya Orang Cina beragama Buddha dan mengamalkan agama tradisi Cina selain beragama Kristian. 
Analisis data berdasarkan agama responden seperti yang ditunjukkan dalam Jadual 4 menunjukkan responden Bumiputera Islam mempunyai tahap toleransi yang sederhana terhadap berkahwin dengan kaum Cina iaitu pada nilai indeks 3.22 berbanding responden Bumiputera bukan Islam yang menunjukkan tahap toleransi yang tinggi iaitu pada nilai indeks 3.68. Walau bagaimanapun, kedua-dua responden yang dibezakan mengikut agama ini pula menunjukkan persamaan iaitu mempunyai tahap toleransi yang sederhana bagi kedua dua bentuk hubungan yang melibatkan menjadi anak angkat dan mengambil anak angkat. Responden Bumiputera Islam didapati mempunyai tahap toleransi yang sederhana bagi kedua dua bentuk hubungan tersebut iaitu pada nilai indeks 3.01 dan 3.22. Manakala responden Bumiputera bukan Islam pula mempunyai nilai indeks toleransi 3.40 dan 3.52.

Jadual 4 : Penerimaan Responden Dalam Konteks Hubungan Kekeluargaan

\begin{tabular}{cccc}
\hline & & \multicolumn{2}{c}{ Indeks Toleransi } \\
Hubungan & & Bumiputera Islam & Bumiputera bukan Islam \\
\hline berkahwin dengan orang Cina & & 3.22 & 3.68 \\
menjadi anak angkat orang Cina & & 3.01 & 3.40 \\
mengambil anak angkat orang Cina & & 3.22 & 3.52 \\
\hline Petunjuk & $3.68-5.0 \quad=$ & Tinggi & \\
& $2.34-3.67 \quad=$ & Sederhana & \\
$1.0-2.33 \quad=$ & Rendah &
\end{tabular}

Seterusnya tahap toleransi etnik responden dianalisis mengikut agama mereka. Analisis toleransi etnik mengikut agama pula seperti yang ditunjukkan dalam Jadual 5, menunjukkan secara keseluruhannya responden kajian mempunyai tahap toleransi etnik yang tinggi terhadap kaum Cina. Walau bagaimanapun seara relatifnya tahap toleransi etnik responden Bumiputera bukan Islam lebih tinggi sedikit berbanding Bumiputera Islam. Perbezaan ini mucul sudah tentunya dipengaruhi oleh penerimaan mereka yang berbeza khususnya dalam konteks hubungan kekeluargaan seperti yang telah dijelaskan di atas.

Jadual 5 : Tahap Toleransi Mengikut Agama

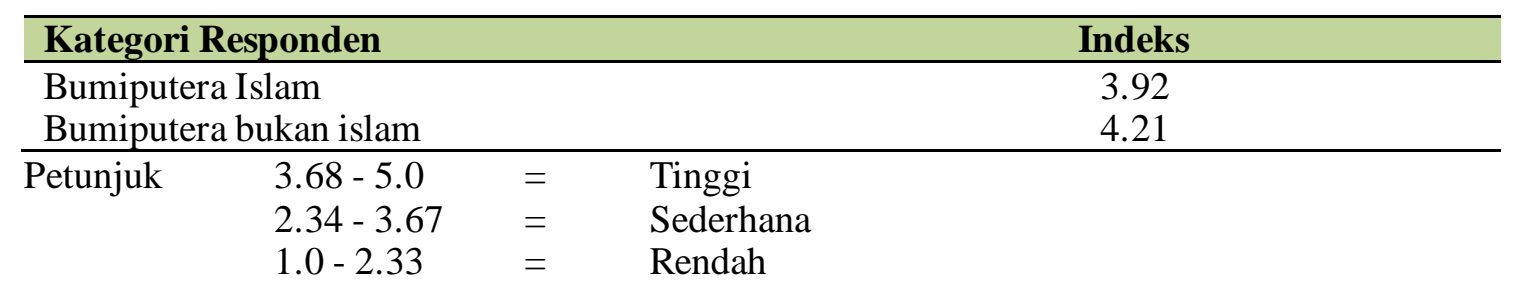

Jika dilihat dari konteks asal responden pula, secara keseluruhannya didapati responden kajian juga mempunyai tahap toleransi etnik yang tinggi terhadap kaum Cina. Walaupun wujud perbezaan tetapi perbezaan tersebut terlalu kecil untuk dibandingkan. Responden yang menetap di kawasan bukan perkampungan tradisional mempunyai tahap toleransi etnik yang lebih tinggi sedikit boleh jadi kerana percampuran mereka dengan kaum Cina lebih kerap berbanding dengan responden yang menetap di kawasan perkampungan tradisional. Perkampungan tradisional biasaya dihuni oleh masyarakat yang mempunyai jalinan hubungan kekeluargaan dan biasanya amat sukar melihat penduduk Cina di kawasan perkampungan tradisional kerana tanah untuk perkampungan tradisional dikhususkan kepada penduduk Bumiputera sahaja dan sukar untuk dibeli oleh orang Cina. Walaupun begitu, tahap toleransi etnik responden yang berasal di perkampungan tradisional juga masih tinggi dan ini menunjukkan bahawa, pola petempatan tidak memberi kesan yang besar mempengaruhi toleransi etnik. 
DOI: https://doi.org/10.47405/mjssh.v5i12.598

Jadual 6 : Tahap Toleransi Mengikut Asal

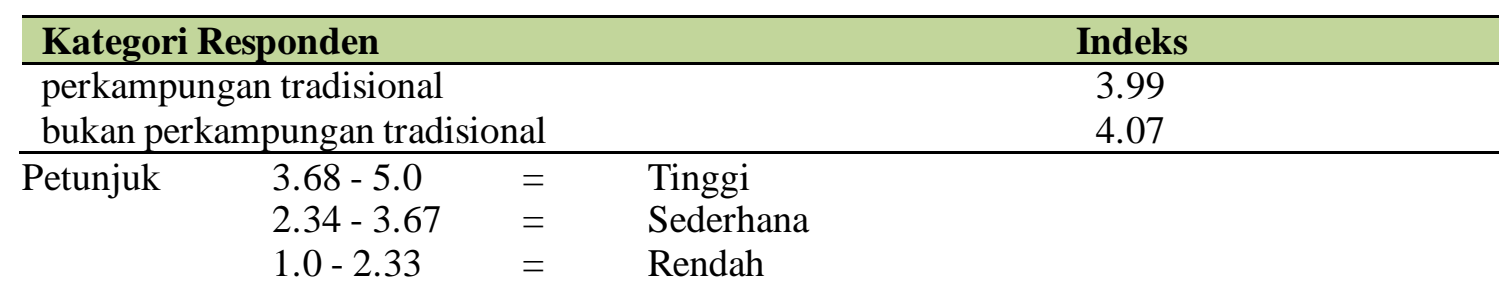

Demikian juga tahap toleransi yang dianalisis berdasarkan jantina. Secara keseluruhannya responden kajian yang dibezakan mengikut jantina tidak menunjukkan perbezaan tahap toleransi etnik yang signifikan untuk dibandingkan. Responden kajian sama ada responden lelaki mahupun perempuan mempunyai tahap toleransi yang tinggi terhadap kaum Cina.

Jadual 7 : Tahap Toleransi Mengikut Jantina

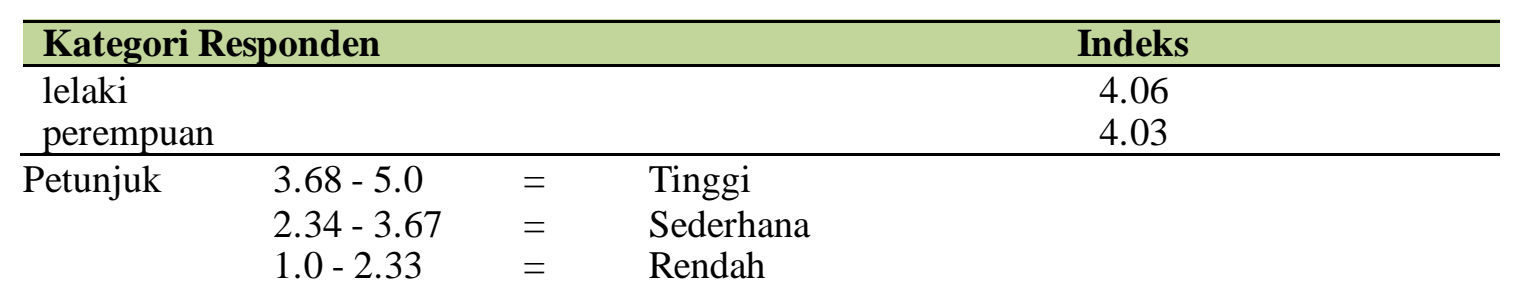

Tahap toleransi responden terhadap kaum Cina jika dilihat dari segi perbezaan jenis sekolah mereka juga didapati tidak mempunyai perbezaan signifikan. Jadual 8 menunjukkan tahap toleransi responden yang bersekolah di sekolah kebangsaan dengan responden yang bersekolah di sekolah bekas aliran sekolah Cina. Sekolah bekas aliran sekolah Cina bermaksud sekolah tersebut pada suatu masa dahulu merupakan sekolah jenis kebangsaan Cina tetapi telah berubah status menjadi sekolah kebangsaan. Walaupun berubah status, sekolah bekas aliran Cina ini masih mempunyai bilangan pelajar Cina yang ramai berbanding di sekolah kebangsaaan yang biasa. Percampuran yang tinggi dengan pelajar Cina boleh jadi menyebabkan tahap toleransi responden yang bersekolah di sekolah bekas aliran Cina didapati lebih tinggi sedikit berbanding responden dari sekolah kebangsaan. Walau bagaimanapun perbandingan tersebut tidak begitu menonjol memandangkan kedua-dua kategori responden secara keseluruhannya juga mempunyai tahap toleransi etnik yang tinggi terhadap kaum Cina.

Jadual 8 : Tahap Toleransi Mengikut aliran sekolah

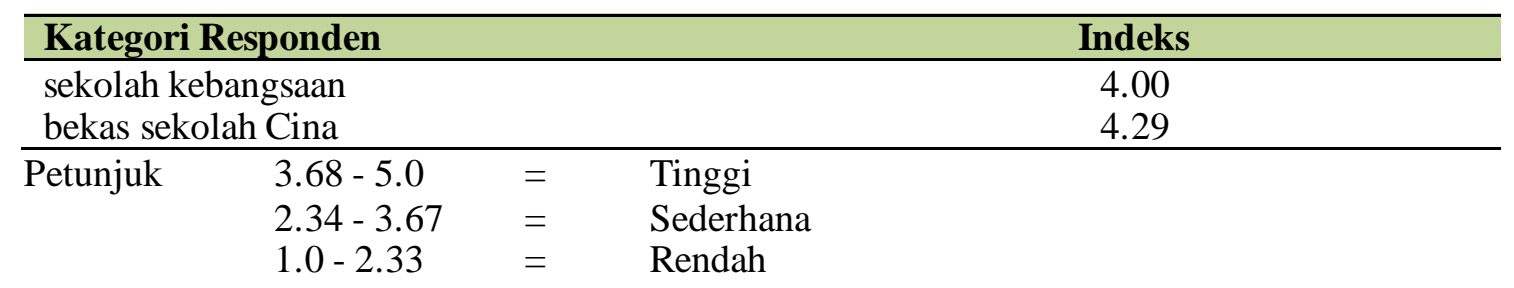

Selain itu, tahap toleransi etnik responden mengikut status perkahwinan ibu bapa mereka juga tidak menunjukkan perbezaan yang ketara untuk dibuat perbandingan. Walaupun responden dari kategori keluarga berkahwin campur mempunyai tahap toleransi yang lebih tinggi sedikit berbanding responden dari keluarga yang tidak berkahwin campur tetapi kedua-duanya masih menunjukkan tahap toleransi yang tinggi. Ini bermakna perkahwinan campur bukanlah satu faktor penting yang mempengaruhi toleransi etnik di Kota Kinabalu mahupun Sabah secara umumnya. Responden Bumiputera dalam kajian ini mempunyai tahap toleransi etnik yang tinggi terhadap kaum Cina boleh jadi disebabkan oleh sifat keterbukaan masyarakat di Sabah telah berkembang sejak sekian lama dan mereka tidak mempunyai masalah dengan perbezaan antara mereka. Identiti kaum yang agak banyak serta percampuran yang tinggi di Sabah menjadikan pergaulan masyarakat merentasi kaum sudah menjadi kebiasaan dan tidak menjadi masalah dalam masyarakat sejak dahulu lagi. 
DOI: https://doi.org/10.47405/mjssh.v5i12.598

Jadual 9 : Tahap Toleransi Mengikut Status Perkahwinan Ibu Bapa

\begin{tabular}{|c|c|c|}
\hline Kategori Responden & & Indeks \\
\hline $\begin{array}{l}\text { kahwin campur } \\
\text { tidak berkahwin campur }\end{array}$ & & 4.06 \\
\hline tidak berkahwin campur & & 4.00 \\
\hline $\begin{array}{l}3.68-5.0 \\
2.34-3.67 \\
1.0-2.33\end{array}$ & $\begin{array}{ll}= & \text { Tinggi } \\
= & \text { Sederhana } \\
= & \text { Rendah }\end{array}$ & \\
\hline
\end{tabular}

\section{Perbincangan Kajian}

Hasil analisis data seperti yang telah diterangkan menunjukkan secara keseluruhannya tahap toleransi etnik pelajar Bumiputera terhadap kaum Cina adalah tinggi. Dapatan ini menggambarkan bahawa jarak sosial antara penduduk di Kota Kinabalu adalah rendah atau dengan erti kata lain prejudis dalam masyarakat adalah rendah. Penduduk Bumiputera di Kota Kinabalu tidak mempunyai masalah untuk menjalinkan pelbagai bentuk hubungan dengan kaum Cina dalam kehidupan seharian mereka.

Walaupun Tahap toleransi etnik adalah tinggi secara keseluruhannya tetapi dalam konteks beberapa jenis hubungan lain didapati adalah sederhana. Analisis terhadap 21 item toleransi yang diukur menunjukkan penerimaan responden adalah berbeza-beza dan dapat dirumuskan seperti yang berikut;

1. Secara keseluruhannya tahap toleransi etnik responden terhadap kaum Cina adalah tinggi. Analisis mengikut agama, asal, jantina, jenis aliran sekolah dan status perkahwinan ibu-bapa tidak menunjukkan perbezaan yang ketara untuk dibuat perbandingan.

2. Responden kajian didapati mempunyai penerimaan yang sederhana terhadap hubungan kekeluargaan. Penerimaan terhadap menjalinkan hubungan intim khususnya dalam konteks hubungan kekeluargaan terhadap kaum Cina adalah pada tahap sederhana. Perbandingan juga dibuat untuk melihat tahap toleransi responden mengikut agama secara khusus dalam konteks hubungan kekeluargaan tetapi perbezaan penerimaan juga tidak begitu menonjol untuk dibuat perbandingan. Cuma penerimaan responden Bumiputera bukan Islam terhadap berkahwin dengan kaum Cina didapati adalah pada tahap tinggi berbanding responden Bumiputera Islam pada tahap sederhana. Penerimaan ini boleh jadi dipengaruhi oleh undang-undang di Malaysia yang tidak membenarkan penganut agama Islam berkahwin dengan pasangan berlainan agama melainkan bertukar agama kepada Islam terlebih dahulu. Manakala responden bukan Islam pula (majoriti responden bukan Islam adalah beragama Kristian) boleh jadi tidak begitu bermasalah untuk berkahwin dengan kaum Cina kerana mempunyai persamaan agama dengan kaum Cina (ada juga penduduk Cina yang beragam Kristian). Selain itu, terdapat juga kes perkahwinan Bumiputera Bukan Islam yang berkahwin dengan pasangan yang berbeza agama dan perkara ini dibenarkan dalam undang-undang adat (Nelson Justen Adeh, 2020). Tetapi dalam kes seperti ini hanya perkahwinan antara sesama pasangan yang bukan beragama Islam sahaja. Bahkan terdapat juga sumber yang menjelaskan penganut agama Kristian boleh berkahwin dengan sesiapa sahaja yang disukai termasuklah berkahwin di antara mazhab dan di antara agama yang berbeza (Roziah Chek, 2010: 132).

3. Responden kajian didapati mempunyai penerimaan yang sederhana terhadap hubungan politik khususnya yang berkaitan isu pemimpin. Dalam konteks politik, penerimaan responden kajian sedikit berbeza apabila diajukan kesanggupan mereka untuk dipimpin oleh kaum Cina. Penerimaan responden untuk dipimpin oleh kaum Cina adalah pada tahap sederhana. Ini bermakna, mereka tiada masalah untuk sepasukan dalam parti politik ataupun pertubuhan sosial dengan kaum Cina tetapi mereka tidak begitu bersetuju sekiranya pemimpin mereka adalah orang Cina. Dapatan ini menunjukkan bahawa, responden Bumiputera mengutamakan pemimpin yang memimpin mereka adalah dari kaum sendiri dan kurang bersetuju menerima orang Cina sebagai pemimpin mereka. 


\section{Kesimpulan}

Secara keseluruhannya, dapatan kajian menunjukkan tahap toleransi responden terhadap kaum Cina adalah tinggi. Dapatan ini mengambarkan bahawa penduduk Bumiputera di Sabah tidak mempunyai masalah untuk menjalinkan hubungan dengan kaum Cina. Keadaan ini juga menjelaskan bahawa tahap toleransi etnik yang tinggi di Sabah seperti mana yang dijelaskan oleh beberapa pengkaji sebelum ini juga mengambarkan bahawa toleransi penduduk di Sabah bukan hanya terhadap sesama kaum Bumiputera sahaja tetapi juga terhadap kaum keturunan imigran.

\section{Penghargaan}

Manuskrip ini dihasilkan daripada geran penyelidikan Persepsi Pelajar Bumiputera Terhadap Kaum Cina Di Sabah: Kajian Kes Di Sekolah Menengah Dalam Daerah Kota Kinabalu (SPSM-PPIB 2019) Universiti Malaysia Sabah.

\section{Rujukan}

Bih Ni, Lee. (2012). Sejarah Awal Pembangunan Dan Kepimpinan Komuniti Cina Di Sabah: 18831961. In: Seminar Antarabangsa Pembangunan Komuniti, 7-9 April 2012, Hotel Permai, Kuala Terengganu.

Bogardus, E. (1925). Social Distance and It's Origins. Journal Of Sociology and Social Research. 9: 216-225.

Budi Anto Mohd Tamring, Bernadette Tobi \& Mohd Sohaimi Esa. (2020). Ethnic Tolerance in Sabah: An Analysis of the Factors Affecting the Harmony of the People in Sabah. Solid State Technology, 63(6), 810-821.

Budi Anto Mohd Tamring \& Saidatul Nornis Hj. Mahali. (2020). Hubungan Kaum di Sabah: Suatu Pemerhatian Awal. Malaysian Journal of Social Sciences and Humanities (MJSSH), 5(10), 95- 104.

Budi Anto Mohd Tamring. (2008). Pengaruh Agama dalam Interaksi dan Toleransi Etnik: Kajian Kes ke atas Pelajar Bumiputera Sabah di Universiti Malaysia Sabah. Tesis Sarjana. Kota Kinabalu. Univertisi Malaysia Sabah. Tidak Diterbitkan.

Budi Anto Mohd Tamring \& Saidatul Nornis Hj. Mahali. (2020). Amalan Kahwin Campur dalam kalangan Masyarakat Di Kota Kinabalu, Sabah. Malaysian Journal of Social Sciences and Humanities (MJSSH), 5(9), 149-162.

Budi Anto Mohd Tamring. (2018). Mikorot Dalam Konteks Kebudayaan Etnik Dusun Di Sabah:Analisis Dari Perspektif Hubungan Etnik. MANU, 27, 93-120.

Budi Anto Mohd Tamring, Mohd Sohaimi Esa \& Mohd Azri Ibrahim (2020). Hubungan Kaum dalam Kawasan Rukun Tetangga (KRT) di Pantai Barat Sabah. Malaysian Journal of Social Sciences and Humanities (MJSSH), 5(11), 147-158.

Budi Anto Mohd Tamring, Natalie Ann Gregory \& Romzi Ationg. (2020). Ethnic Interaction Experience Of Chinese Ethnic Students: A Case Study In Universiti Malaysia Sabah. Solid State Technology, 63(6), 789-800.

Buku Tahunan Jabatan Perangkaan Sabah (2014). Statitic Yearbook 2014: 8-10

Roziah Chek. (2010). Konsep Perkahwinan Dalam Islam Dan Kristian : Kajian Perbandingan. Tesis Master. Kuala Lumpur. Jabatan Akidah Dan Pemikiran Islam Akademi Pengajian Islam Universiti Malaya

Harmiza Maula Mokhatar (2015) Persepsi antara etnik dan impaknya terhadap hubungan etnik dalam kalangan belia Melayu dan Cina di Semenanjung Malaysia. Masters thesis, Universiti Putra Malaysia.

Hasan Mat Nor (2007). Agama dan Hubungkaitnya Dengan Toleransi Etnik Di Sabah dalam Sabihah Osman. Toleransi Etnik dan Perpaduan Sosial. Laporan Penyelidikan IRPA. Tidak Diterbitkan.

Herman Luping. (2010). Ancestors, parents and native status. Atas Talian http://www.dailyexpress.com.my/read.cfm?NewsID=500. Diakses pada 27/11/2020. 
DOI: https://doi.org/10.47405/mjssh.v5i12.598

Jabatan Perangkaan. (2010). Komposisi Penduduk Sabah. Atas Talian https://www.statistics.gov.my/censusatlas/images/ReligionEN.pdf. Diakses pada 7/11/2020

Kamarul Azmi Jasmi et,al. (2011). Persepsi Masyarakat Parlimen Pekan Terhadap Gagasan 1Malaysia. Atas

Talian https://www.researchgate.net/publication/293097764_Persepsi_masyarakat_parlimen_Pekan_terh a dap_gagasan_1Malaysia. Diakses pada 28/11/2020.

Kntayya Mariappan. (2007). Tahap Toleransi Etnik Di Sabah: Analisis Awal dalam Sabihah Osman. Toleransi Etnik dan Perpaduan Sosial. Laporan Penyelidikan IRPA. Tidak Diterbitkan.

Landell, K. (1997). Management By Menu. 1. ed. London: Wiley and Sons Inc.

Mansor Mohd. Noor. (2010). Hubungan Melayu dan Cina di Malaysia Masa Kini: Buta dengan Perubahan Realiti Sosial Negara. Atas Talian http://103.216.87.80/index.php/jd/article/view/1424. Diakses pada 7/11/2020.

Mohamed Ali bin Haniffa (2016). Pendudukan Jepun dan Konflik Kaum di Tanah Melayu: Penelitian Awal Berasaskan Sumber Lisan. Atas Talian https://www.researchgate.net/publication/299453079_KONFLIK_MELAYUCINA_SELEPAS_P ENDUDUKAN_JEPUN_DI_TANAH_MELAYU. Diakses pada 8/11/2020

Mohd Sohaimi Esa, Dayu Sansalu \& Budi Anto Mohd Tamring. (2011). Hubungan Etnik: Kelangsungan Pembinaan Negara Bangsa. Penerbitan Multimedia.

Nelson Justin Adeh. (2020). Temubual tentang perkahwinan berlainan agama dalam kalangan Bumiputera bukan Islam di Sabah pada 28/11/2020.

Noor Aida Ishak. (2009). Hubungan etnik (Melayu) dan Cina) di Pahang: kajian kes di Felda Melati Jengka 11, Bandar Jengka. Jabatan Sosio-Budaya Melayu, Akademi Pengajian Melayu, Universiti Malaya.

Nunnally, J., \& Bernstein, I. (1994). Psychometric Theory:3rd edition. New York: McGraw Hill.

Sabihah Osman. (2007). Toleransi Etnik dan Perpaduan Sosial. Laporan Penyelidikan IRPA. Tidak Diterbitkan.

Siti Aisyah Ramli. (2017). Utusan Borneo Online. Sarawak, Sabah contoh integrasi dan perpaduan. Atas Talian https://www.utusanborneo.com.my/2017/06/03/sarawak-sabah-contoh-integrasi-danperpaduan. Diakses pada 7/11/2020.

Suraya Sintang, Budi Anto Mohd Tamring, Nur Farhana Abdul Rahman, Siti Aidah Hj. Lukin \& Halina Sendera Mohd. Yakin. (2019). Kesepaduan Sosial dalam Hubungan antara Agama di Pedalaman Sabah. Borneo International Journal, 2(1), 5-15. 